\title{
Особенности межкадровой обработки последовательности изображений, формируемых сканирующим устройством на основе многорядного ФПУ
}

\author{
Г.И. Громилин ${ }^{1)}$, В.П. Косых ${ }^{1,2)}$, С.А. Попов ${ }^{1)}$, Б.Н. Дражников ${ }^{3)}$, К.В. Козлов ${ }^{3)}$, В.А. Стрельцов ${ }^{3)}$ \\ ${ }^{1}$ Институт автоматики и электрометрии СО РАН, Новосибирск, 630090, пр. Ак. Коптюга, 1, \\ ${ }^{2}$ Новосибирский государственный университет, Новосибирск, 630090, ул. Пирогова, 2, \\ ${ }^{3}$ АО «НПО «Орион», Москва, 111538, ул. Косинская, 9 \\ тел:+7 913 901-4726, , эл. почта: kosych@iae.nsk.su
}

DOI 10.34077/RCSP2019-141

Среди задач глобального мониторинга земной поверхности одной из актуальных является задача обнаружения слабоконтрастных малоразмерных динамических объектов в последовательности изображений, содержащих мощный пространственно-неоднородный фон. Межкадровая обработка (МКО) изображений [1] является одним из методов снижения порога обнаружения динамических объектов за счет эффективного подавления фона. Для формирования крупноформатных изображений сравнительно медленно изменяющихся сцен могут применяться сканирующие приборы на основе многорядных фотоприемных линеек [2], которые, обеспечивая повышенное разрешение, являются конкурентоспособной альтернативой «смотрящим» матричным фотоприемникам. Однако, как показано в [3], отклонение скорости сканирования от номинала приводит к ряду искажений, существенно влияющих на надежность обнаружения малоразмерных объектов.

В работе предлагается способ МКО, основанный на пофрагментной компенсации смещения фона с точностью до долей шага дискретизации, значительно снижающий влияние нестабильности скорости сканирования. На рисунке приведен результат подавления фона посредством вычисления межкадровой разности (скорость сканирования в соседних кадрах отличается на $0.1 \%$ ) при различных способах компенсации смещения. СКО фона (в квантах АЦП) в исходной последовательности $(a)$ равно 144 квантам при СКО шума 6.5 квант, в разности без компенсации смещения - от 9.2 до 101.6 кванта, в разности с целочисленной компенсацией (в) - от 9.6 до 18.1 кванта, в разности с дробным совмещением (2) - 9.8 кванта.

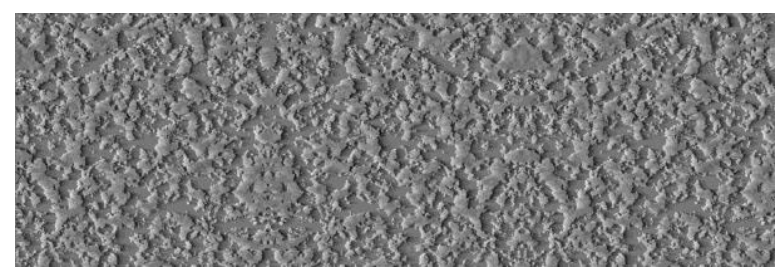

$a$

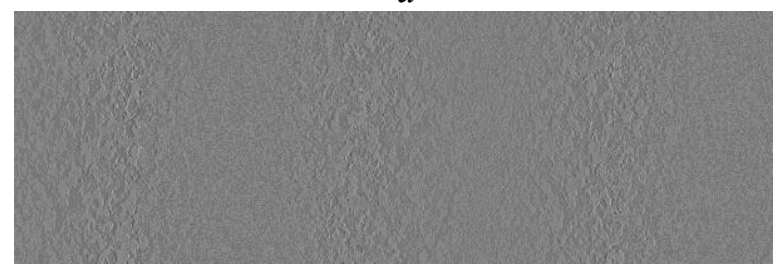

B



6



Межкадровая обработка: $a$ - один из исходных кадров последовательности, $\sigma$ - разность двух последовательных кадров, 8 - разность с целочисленной компенсацией смещения фрагментов, 2 разность с дробной компенсацией смещения фрагментов. Контраст в и г увеличен в 4 раза по сравнению с $a$

\section{Лuтература}

[1] В.С. Киричук и др. Подавление квазистационарного фона в последовательности изображений посредством межкадровой обработки // Автометрия, 2014, т.50, № 2. С. 3 - 13

[2] П. А. Кузнецов и др. Фотоприемные модули с режимом ВЗН для мониторинга земной поверхности в ИК-диапазоне // Успехи прикладной физики, 2014, т. 2, № 6, С. 635-638 [3] Г.И. Громилин и др. Моделирование процесса сканирования изображений с использованием матричных фотоприемников // Труды XXIV Международной научно-технической конференции по фотоэлектронике и приборам ночного видения.. ГНЦ РФ АО "НПО "Орион", Москва, 2016, с. 200-205 